\title{
DỨBin
}

Technological University Dublin ARROW@TU Dublin

\section{Emotional intelligence and conflict management styles}

\author{
Helen Chen \\ Technological University Dublin, helen.chen@tudublin.ie \\ Xuemei Xu \\ Dongbei University of Finance And Economics \\ Patrick Phillips \\ Trinity College Dublin, Ireland
}

Follow this and additional works at: https://arrow.tudublin.ie/buschmarart

Part of the Business Administration, Management, and Operations Commons

\section{Recommended Citation}

Chen, H.X., Xu, X. and Phillips, P. (2019), "Emotional intelligence and conflict management styles", International Journal of Organizational Analysis, Vol. 27 No. 3, pp. 458-470. DOI: 10.1108/

IJOA-11-2017-1272

This Article is brought to you for free and open access by the School of Marketing at ARROW@TU Dublin. It has been accepted for inclusion in Articles by an authorized administrator of ARROW@TU Dublin. For more information, please contact arrow.admin@tudublin.ie, aisling.coyne@tudublin.ie,gerard.connolly@tudublin.ie. 
IJOA

27,3

\section{8}

Received 6 November 2017 Revised 27 March 2018 Accepted 29 March 2018

\title{
Emotional intelligence and conflict management styles
}

\author{
Helen X. Chen \\ School of Marketing, Dublin Institute of Technology, Dublin, Ireland \\ Xuemei Xu \\ School of Public Administration Management, \\ Dongbei University of Finance and Economics, Dalian, China, and \\ Patrick Phillips \\ School of Business, Trinity College Dublin, University of Dublin, Dublin, Ireland
}

\begin{abstract}
Purpose - This paper aims to use a multi-level approach to examine the effects of emotional intelligence (EI) components on conflict management styles of Chinese managers when the respondents were in conflicts with their subordinates, peers or superiors.

Design/methodology/approach - The primary research was conducted in Dalian, China, via a personal survey resulting in 885 usable observations for analysis. EI was measured using the Wong and Law Emotional Intelligence Scale (WLEIS; Wong and Law, 2002), which is made up of 16 questions measuring four dimensions. The conflict management component was measured via Rahim's (1983) five conflict management styles, which are avoidance, dominating, collaboration, compromise and integration.
\end{abstract}

Findings - The data analyses suggested that managers at different levels possess different EI and adopt different conflict management styles when dealing with their subordinates, peers and superiors. Specifically, when subordinates were involved in a conflict, junior managers and female managers were more likely to use the dominating style, while when peers were involved in a conflict, male managers were more likely to use the dominating style. When peers were involved in a conflict, managers working in public sectors were more likely to adopt the integrating, avoiding, obliging and compromising style. The Chinese managers were found to regulate their emotions and use of their emotions effectively in conflict with their peers and supervisors and thus they tended to adopt the avoiding, integrating and obliging style. Self-emotions appraisal and others emotions appraisal were significant to the adoption of the obliging style to handle conflict with their peers and supervisors. Use of emotions effectively was significant for the Chinese managers adopting the compromising style in conflicts with their peers, superiors and subordinates.

Research limitations/implications - The authors could only reach employees working and living in one city, which affects the generalizability of the paper.

Practical implications - Training should be provided to managers at different levels on the awareness of the impact of EI on conflict management at workplace.

Originality/value - There is little existing research on how employees across different levels within organisations in China moderate their EI according to the party they are interacting with. The objective of this paper is to stimulate further debate on the matter, thereby improving the understanding of EI moderation.

Keywords China, Multilevel analysis, Emotional intelligence, Conflict management

Paper type Research paper

\section{Introduction}

Conflicts result from human interaction (Darling and Walker, 2001) and therefore Weiss and Hughes (2005) argue that conflicts are inevitable within organisations. As interpersonal conflicts are execrable, it has been recommended that organisations avoid them. Much work 
has been done on conflict management. In particular, research conducted by Ting-Toomey (1999) suggested that emotional expression is a primary component of conflict management. The self-construal approach (Ji, 2012) highlights the thoughts, feelings and actions of someone being linked with other people. Some research such as Thomas (1992), Jehn (1995), Jordan and Troth (2004) and Moeller and Kwantes (2015) have all posited that an individual's conflict management style may be affected by their level of emotional intelligence (EI). The correlation has been proven to be positive (Ann and Yang, 2012) or mixed (Abas et al., 2014; Conine and Leskin, 2016). However, it is not known how employees at different managerial levels with different levels of EI manage conflicts that involve their subordinates, peers or superiors. Thus, this study is an attempt to attain such an objective.

\section{Research background}

\subsection{Conflicts and conflicts management}

Interpersonal conflicts arise in the workplace at all levels because of different "goals, expectations, values, proposed courses of action and suggestions about how to handle a situation" (Darling and Walker, 2001 p. 230), or "when confronting interests or incompatible activities exist" (Aritzeta et al., 2005, p. 161). Thomas (1992) provided two approaches in which interpersonal conflicts can be defined: process and structure. In the process model, frustration, conceptualisation, behaviour and outcome are a sequence of events in a conflict, while in the structure model, "stable conditions (or parameters)" (p. 267) are the focus (Thomas, 1992). There currently exists a substantial amount of literature on the impact of conflict within organisations. Some scholars such as Jehn (1995) and Darling and Walker (2001) believe that conflict is detrimental to the successful operation of an organisation and represents "a sign of a problem" (Darling and Walker, 2001, p. 230). Others believe interpersonal conflict can be beneficial, and organisations that accept and work through conflicts can be described as "good organisations" (Hellriegel et al., 1995, p. 430). Nevertheless, the cost of interpersonal conflict is well documented in areas such as job satisfaction, organisational commitment, and turnover (Jehn, 1995, 1997). Therefore, it could be argued that interpersonal conflicts are lamentable, and need to be avoided or minimised within the workplace (Ann and Yang, 2012). Conflict management refers to the specific behavioural patterns that employees employ in the event of a disagreement (Moberg, 2001). It has been argued by Weiss and Hughes (2005) that improper management of existing conflicts may cause them to persist, while also creating the conditions to enable further confrontations to occur.

There currently exist many different theoretical models to approach conflict management. Jehn (1997), treats conflict management as a process, and thus focuses on a cognitive bargaining process (Nair, 2007). Alternatively, Deutsch (1949), Pruitt (1983) and Rahim (1983) treats it as a dimension of concern for self and productivity, and therefore the approach to conflict management relates more to different types of styles. Among them, Deutsch (1949) proposed a uni-dimensional approach of cooperation and competition style; Pruitt (1983) suggested a bi-dimensional approach involving four styles of conflict management; Darling and Walker (2001) also proposed a bi-dimensional model; so did Blake and Mouton (1964) and Rahim and Bonoma (1979). The latter in particular, involved five styles. Horney (1945) worked out a tri-dimensional model compromising three styles.

The present study did not take a longitudinal approach, and for this reason, different conflict management styles were adopted. With this in mind, Blake and Mouton's (1964) model is "the most extended model" (Aritzeta et al., 2005, p. 162). Rahim (1983), following this approach, developed his five conflict management styles by using two dimensions 'concern for self' and 'concern for others' (Figure 1). In his model, the five styles for conflict 
IJOA

27,3

460

\section{Figure 1.}

The bi-dimensional model of conflict management styles

\section{Concern for self}

High Low

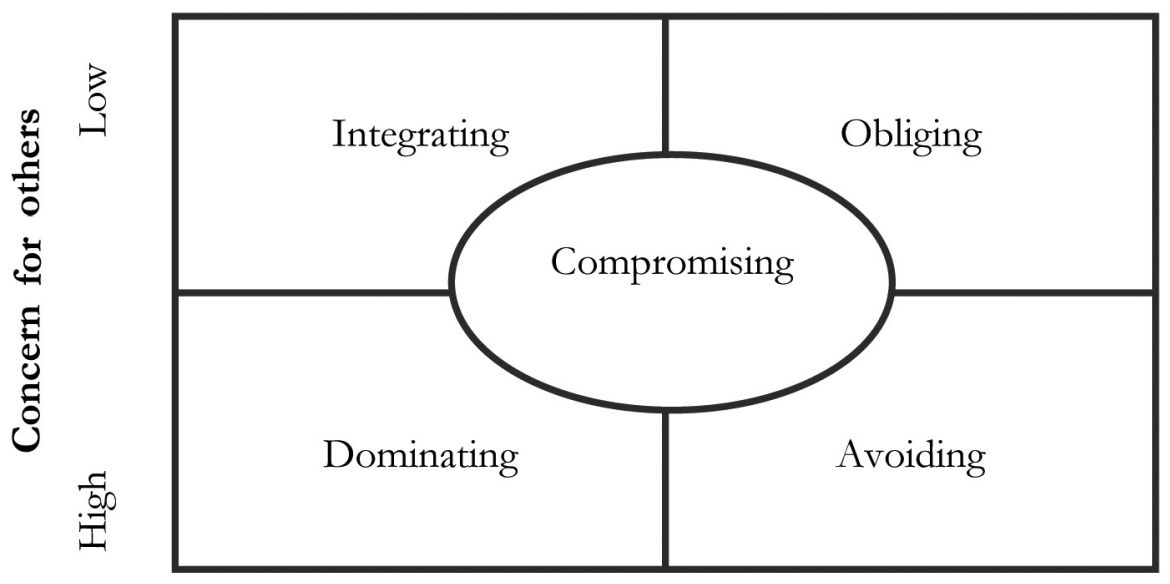

Source: Rahim (1983)

management are integrating, avoiding, dominating, obliging, and compromising. The first dimension measures the extent to which an individual looks after their own interests, while the second dimension examines the degree to which a person demonstrates concern for others (Rahim and Bonoma, 1979).

The integrating style reflects a high concern for self as well as for others. The party who adopts the integrating style shows empathy for the other, and seeks to reconcile both theirs, and the other party's interests (Aquino et al., 2006). They will also seek to exchange information (Aritzeta et al., 2005), and/or examine both points of view (Rahim and Magner, 1995). When conflicted parties show low levels of concern for others' interests and a low level of concern for oneself, they can be described as adopting the avoiding style. By using the style of avoidance, the involved party simply wants to withdraw from conflict by "sidestepping" the issue or adopting a "see no evil, hear no evil, speak no evil" approach (Rahim and Magner, 1995, p. 123) or by "hiding disagreement" (Aritzeta et al., 2005 p. 165), which can also be described as a withdrawal from the problem (Rahim, 1983). Similar to the avoiding style, the dominating approach incorporates an imbalance between concerns for self and for others. The dominating style involves high levels of concern for self while ignoring others' interests and the party who adopts this style considers conflict as a win-lose war. Therefore, it is likely they will seek to impose their opinions and ideas on the other party (Rahim and Magner, 1995). Aritzeta et al. (2005) posit that those adopting the dominating style intend to obtain favourable solutions for themselves only. Furthermore, it is often considered an aggressive style (Rahim, 1983). The obliging style tends to be adopted by those individuals who attempt 'to play down the differences and emphasises commonalities to satisfy the concerns of the other party' (Rahim and Magner, 1995, p. 123). The compromising style shares commonalities with all of the other four styles (Thomas, 1992; Rahim and Magner, 1995). It requires the conflicting parties to consider both 
themselves as well as others. It is a "give-and-take or sharing" approach (Rahim and Magner, 1995, p.123), which by its nature requires compromise.

\subsection{Emotional intelligence}

$\mathrm{EI}$ is woven into the fabric of conflict management (Rahim and Psenicka, 2002; Jordan and Troth, 2004) as conflicts are, as previously stated, emotionally charged human interactions. Jordan and Troth (2004) argue that if emotions are successfully managed, a conflict scenario has an increased likelihood of being resolved successfully. Furthermore, Johnson and Johnson (2000) suggested EI might help individuals to redress conflict. Ayoko et al. (2003) proposed that positive emotional experiences might enable individuals to manage conflict in a more constructive way. Conflict might well affect job satisfaction, which in turn can impact staff retention and turnover, therefore EI has been associated with a range of positive outcomes for organisations (Wong and Law, 2002; Shil and Susanto, 2010). As argued in Cartwright and Pappas (2008), EI is associated with increased performance, which is appealing to any organisation.

EI has been researched extensively, by Goleman (1995, 1998), Bar-On (1997) and Mayer and Salovey (1997). Salovey and Mayer (1990) were among the first to establish the term EI by defining it as 'the ability to monitor one's own feelings and emotions, to discriminate among them, and to use this information to guide one's thinking and actions' (Kerr et al., 2006, p. 289). Their conceptualisation of EI has provided a foundation or inspiration to models, such as the multifactor EI scale (MEIS by Mayer et al., 1999); the emotional competency inventory (ECI by Goleman, 1998); the emotional quotient inventory (EQ-I by Bar-on, 1997); and the self-report EI test (SREIT by Schutte et al., 1998). These models have different focuses, and use different measurements. MSCEIT by Mayer et al. (2000) for example use 141 items to understand individuals EI, while ECI contains 133 items, and SREIT 33 items. They all demonstrate differing conceptual foundations. Some focus "exclusively on cognitive aptitudes" (Kerr et al., 2006; p. 266) and are classified as "ability models of EI", such as Caruso et al. (2002) (Kerr et al., 2006, p. 266). Others focus not only on abilities, but also on behaviour and personality, they are classified as "mixed models of EI", such as those discussed in Mayer et al. (2000) as cited in Kerr et al. (2006, p. 266).

For the purposes of this study, Salovey and Mayer (1990)'s approach was used in treating EI as a mixture of ability, personality and behaviour. In the work of Mayer et al. (2000), EI has been categorised into four groups, i.e. awareness of one's own emotions, understanding others' emotions, managing one's own emotions and the proper use of one's own emotions.

\section{Methods}

\subsection{Sample}

A total of 1,061 managers working and living in the city of Dalian in Liaoning Province, China participated in the study. It took two months to complete the data collection via personal surveys. The researchers used the MBA and MPA alumni members of a national university in Dalian to gain access to different types of organisations, government departments, state-owned enterprises, privately owned companies and foreign-invested companies. Because of missing data, only 885 questionnaires were usable, which accounted for 83 per cent of total participation.

\subsection{Questionnaire design and measures}

EI was measured by using the Wong and Law Emotional Intelligence Scale (WLEIS; Wong and Law, 2002), which is made up of 16 questions measuring four dimensions. This approach, as discussed earlier, is a suitable business study version of Salovey and Mayer 
IJOA

27,3

(1990), in which they simplified the number of measures (Moeller and Kwantes, 2015). In relation to conflict management measurement, Rahim's (1983) five conflict management styles were adopted, which as previously stated are avoidance, domination, obligation, compromise and integration.

There is a critical question in the questionnaire, which asked the respondents to indicate which style of conflict management they chose to adopt in relation to their subordinates, peers or superiors. It is believed that because of the differing nature of work relationships, employees use different conflict management styles, and in turn will activate different parts of their EI (Suliman and Al-Shaikh, 2006). The questionnaire was originally designed in English and was then translated by a bi-lingual researcher into Chinese. A back translation was completed by another bi-lingual researcher to ensure the consistency of the two versions.

\section{Results and discussion}

Initially, the respondents were asked to identify the level of seniority of the other party in the conflict management scenario they reported. Interestingly, the findings suggested that 27.8 per cent of high-level managers, 54.3 per cent of middle-level managers and 65 per cent of junior-level managers evaluated their conflict management styles with their peers. On the other hand, 19 per cent of high-level managers, 27.4 per cent of middle-level managers and 26.7 per cent of junior-level managers assessed their conflict management styles in relation to their supervisors. 53.2 per cent of high-level managers, 18.3 per cent of middle-level managers and 8.2 per cent of junior-level managers reported their conflict management styles with their subordinates. In total, 55.4 per cent of male and 61.8 per cent of female respondents evaluated their conflict management styles with their peers; 26.8 per cent of male and 26.4 per cent of female respondents did so with their supervisors; and 17.8 per cent of male and 11.7 per cent of female respondents reported their conflict management styles involving their subordinates. 38.2 per cent of managers were aged between 22-30 years old, 34.9 per cent of were between 31-40 years old, 18.6 per cent were between 41-50 years of age and 8.3 per cent of them were aged between 51 and 55. Table I presents the conflict management styles of the respondents when a subordinate, peer or superior is involved.

Exploratory factor analysis and confirmatory factor analysis were both performed to confirm the five styles of conflict management and the four EI components (Figure 2).

Figure 2, with the CFI being 0.983 and RMSEA being 0.039 , shows confirmation of the validity of the four components of EI, which are regulating own emotions (ROE), use own emotions in adaptive ways (UOE), self-emotion appraisal (SEA) and others' emotion appraisal (OEA), which supported previous research such as that of Mayer and Salovey (1997) and Cartwright and Pappas (2008). Five conflict management styles were confirmed by CFA, with the CFI being 0.902 and the RMSEA being 0.042 , which corresponded to Rahim et al. (1992) in which there are five conflict management styles, i.e. integrating, avoiding, dominating, obliging, and compromising. In the next step, the data was split into three sub-sets using one variable namely with whom the respondents chose to evaluate their conflict management styles, their subordinates, peers or supervisors. Five models were created to evaluate the effects of EI components on conflict management styles and the results are presented in Table II.

\subsection{Emotional intelligence components and the adoption of the integration style}

Two components of EI proved to be significant in relation to the integration approach and these are, regulation of own emotions (ROE), and UOE with peers or supervisors. According 


\begin{tabular}{|c|c|c|c|c|c|}
\hline Style & Peers & Supervisors & Subordinates & Total & $\begin{array}{l}\text { Conflict } \\
\text { management }\end{array}$ \\
\hline $\begin{array}{l}\text { Integrating } \\
\text { Count } \\
\% \text { within style } \\
\% \text { within others }\end{array}$ & $\begin{array}{c}205 \\
60.1 \\
38.8\end{array}$ & $\begin{array}{l}77 \\
22.6 \\
34.7\end{array}$ & $\begin{array}{l}59 \\
17.3 \\
44.0\end{array}$ & $\begin{array}{l}341 \\
100.0 \\
38.5\end{array}$ & styles \\
\hline $\begin{array}{l}\text { Avoiding } \\
\text { Count } \\
\% \text { within style } \\
\% \text { within others }\end{array}$ & $\begin{array}{c}129 \\
61.4 \\
24.4\end{array}$ & $\begin{array}{l}55 \\
26.2 \\
24.8\end{array}$ & $\begin{array}{l}26 \\
12.4 \\
19.4\end{array}$ & $\begin{array}{l}210 \\
100.0 \\
23.7\end{array}$ & 463 \\
\hline $\begin{array}{l}\text { Dominating } \\
\text { Count } \\
\% \text { within style } \\
\% \text { within others }\end{array}$ & $\begin{array}{l}35 \\
53.8 \\
6.6\end{array}$ & $\begin{array}{l}14 \\
21.5 \\
6.3\end{array}$ & $\begin{array}{l}16 \\
24.6 \\
11.9\end{array}$ & $\begin{array}{c}65 \\
100.0 \\
7.3\end{array}$ & \\
\hline $\begin{array}{l}\text { Obliging } \\
\text { Count } \\
\% \text { within style } \\
\% \text { within others }\end{array}$ & $\begin{array}{l}81 \\
65.9 \\
15.3\end{array}$ & $\begin{array}{l}31 \\
25.2 \\
14.0\end{array}$ & $\begin{array}{c}11 \\
8.9 \\
8.2\end{array}$ & $\begin{array}{c}123 \\
100.0 \\
13.9\end{array}$ & \\
\hline $\begin{array}{l}\text { Compromising } \\
\text { Count } \\
\% \text { within style } \\
\% \text { within others }\end{array}$ & $\begin{array}{l}79 \\
54.1 \\
14.9\end{array}$ & $\begin{array}{l}45 \\
30.8 \\
20.3\end{array}$ & $\begin{array}{l}22 \\
15.1 \\
16.4\end{array}$ & $\begin{array}{l}146 \\
100.0 \\
16.5\end{array}$ & \\
\hline $\begin{array}{l}\text { Total } \\
\text { Count } \\
\% \text { within style } \\
\% \text { within others }\end{array}$ & $\begin{array}{c}529 \\
59.8 \\
100.0\end{array}$ & $\begin{array}{c}222 \\
25.1 \\
100.0\end{array}$ & $\begin{array}{c}134 \\
15.1 \\
100.0\end{array}$ & $\begin{array}{l}885 \\
100.0 \\
100.0\end{array}$ & $\begin{array}{r}\text { Table I. } \\
\text { Conflict management } \\
\text { styles for different } \\
\text { relationships }\end{array}$ \\
\hline
\end{tabular}

to Rahim (1983), the integrating style involves a high level of consideration for oneself as well as others. By regulating their own emotions, Chinese managers are better able to take on board the interests of others. This is in alignment with the work of Aquino et al. (2006), in which the integrating style relates to the reconciliation of the interests of both conflicting parties interests. Another research finding demonstrated that, compared to handling conflicts with subordinates and peers, handling conflict with their superiors involved a higher level of understanding of the EI on the part of the Chinese managers, which is more likely to require an adoption of the integrating style. Compared with handling conflicts with superiors and subordinates, in conflict management with peers, the Chinese managers tended to be not only aware of their own emotions, but also those of others' in addition to regulating their own emotions and using them in adaptive ways. When managing conflicts with subordinates Chinese managers appeared to have less understanding of their own emotions as well as the emotions of others, with the coefficients at 0.147 and 0.048 , respectively. Among the control variables, only sector plays a significant role in predicting the use of the integrating style in handling conflicts with peers. In particular, it is the people who work in the public sectors who are inclined to use the integrating styles compared with their counterparts working in the private sectors.

\subsection{Emotional intelligence components and the adoption of the avoiding style}

In Table II, ROE and UOE were reported by the respondents as a significant variable among those who chose the avoiding style in handling conflicts with their peers or superiors only. 
IJOA

27,3

464

Figure 2.

Exploratory factor analysis of EI

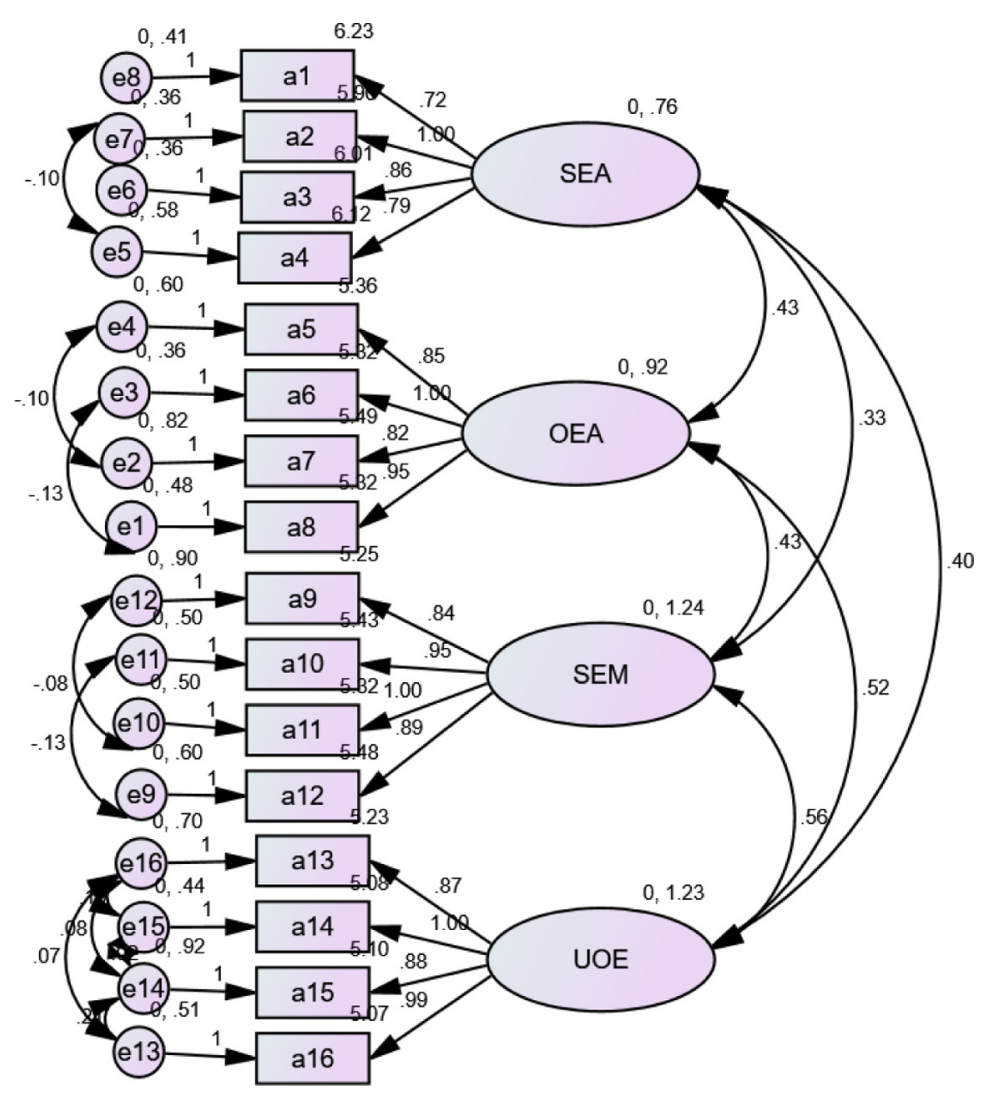

The results indicated there was no need for the Chinese managers to be aware of their own or other people's feelings in adopting the avoiding style when subordinates were involved. According to the findings these two components of EI, (ROE and UOE) are not significant in affecting respondents handling of conflicts with their subordinates when adopting the avoiding style, thus reflecting the "side-stepping", "see no evil, hear no evil, speak no evil" (Rahim and Magner, 1995, p. 123) approach. As they tended not to express disagreement, there was no need to understand their own, or other people's feelings to avoid conflict (Aritzeta et al., 2005). Another interesting finding suggests that when managing conflicts with their superiors, the appraisal of other people's emotions is particularly significant to the extent that avoiding conflicts with superiors probably is the best way to make the Chinese managers feel better.

Among the control variables, employees working in the public sector are more likely to adopt the avoiding style in handling conflicts with their peers and superiors as they demonstrated higher EI; therefore, they are adept in hiding their disagreement with their peers and superiors. Another interesting finding suggests that Chinese managers with lower levels of education demonstrated an increased likelihood of adopting the avoiding style in handling conflicts with their peers. It is interesting to discover that education has a significant negative effect on the avoiding style when the conflicts involved peers. 
IJOA

27,3

\subsection{Emotional intelligence components and the adoption of the dominating style}

Table II shows the respondents did not appear to activate their EI at all when the dominating style is recruited to manage conflict with their subordinates. It is hypothesised here that this might reflect the fact that the power distance in China is high, and employees have a tendency to accept this unfairness in society (Ji, 2012). Appraisal of one's own emotions and those of others plays a significant role in predicting the adoption of the dominating style in handling conflicts with peers or superiors. By adopting the dominating style, the involved party might obtain a favourable position in the conflict (Rahim, 1983). $\mathrm{ROE}$ is not found to have any impact on the adoption of the dominating style in a conflict involving either subordinates, peers or superiors. Nevertheless, this is not to say the Chinese managers do not evaluate the emotions of their peers or superiors when these two were involved in conflicts. Female employees are more likely than their male counterparts to adopt the dominating style when they are involved in a conflict with their subordinates. On the other hand, while handling conflicts with their peers, male employees are more likely to adopt the dominating style than their female counterparts. This supported Ann and Yang (2012). Furthermore, junior managers are also more likely to adopt the dominating approach than their senior managers in managing conflicts with subordinates.

\subsection{Emotional intelligence components and the adoption of the obliging style}

It is evident in Table II that two components of EI, i.e. ROE and UOE, are significant in Chinese employees' adoption of the obliging style in handling conflicts with their peers or superiors. They regulate their emotions, and use their emotions appropriately to oblige peers or superiors. An obliging person has a tendency to play down interpersonal differences (Rahim and Magner, 1995). Therefore, giving up their own personal opinions to manage a conflict requires a high level of regulation of one's own emotions. Employees working in public sectors are more inclined to adopt the obliging style in managing conflicts with their peers. When handling conflicts with subordinates, only those Chinese managers who tend to consider their subordinates' emotions tended to adopt the obliging approach. This finding supports Rahim (1983) who found that the obliging style involved higher levels of concern for others. However, in relation to conflicts involving peers or superiors, SEA and other emotions (OEA) are not as important because of the high power distance culture which requires junior staff to demonstrate a subservient stance in front of their superiors (Ji, 2012). Table II also indicates that the Chinese managers working in the public sectors were more likely to use the obliging styles than their counterparts working in the private sectors when their peers were involved in conflicts.

\subsection{Emotional intelligencecomponents and the adoption of the compromising style}

As the compromising style represents an equal balance of concern for self and for others (Rahim et al., 1992), we have seen the importance of EI, particularly when a conflict involves a colleague and a supervisor. When conflict occurs between Chinese managers and their subordinates, they adopt the compromising style, thereby requiring the correct use of their own emotions in adaptive ways (UOE). To surrender ones interests to obtain some favours from others is the definition of the compromising style (Rahim and Magner, 1995). In comparison, Chinese managers would be more likely to adopt the compromising style in a conflict with their peers or superiors, in which their EI is highly influential, supporting Abas et al. (2014). Public sector managers are inclined to adopt the compromising style when a conflict occurs between them and their peers. Age shows its significance in managing conflict with peers, whereby younger employees are more likely to adopt the compromising style than their older counterparts in managing conflict with their peers. As compromising 
relates to balancing the interests of both parties involved in a conflict (Rahim and Magner, 1995), older managers might be lacking in the requisite skills to implement this approach.

\section{Theoretical contributions}

Conflict management styles

This study responds to a lacuna in existing in current research on the effects of different components of EI in conflict management among manager at different levels of seniority, and with differing EI scores. Most existing literature acknowledges the effect of EI on conflict management in general, but little is known about which specific component of EI is significant in conflict management. In addition, little is known about how employees use their EI to manage conflict with subordinates, peers and superiors.

\subsection{Emotional intelligence and the integrating style}

$\mathrm{ROE}$ and use of emotions adaptively (UOE) played a significant role in managers' adoption of the integrating style in conflict involving subordinates, peers and supervisors. In Rahim (1983), it is the concern for self and others that make the integrating style popular. In our study, we found that in conflicts involving the integrating style for their superiors, managers do not appraise their own emotions; for their peers, they appraise their own and their peers' emotions; for their subordinates, the integrating style is not a popular option. Our results demonstrated that in adopting the integrating style managers did not use their own emotions at all when interacting with superiors. In regard to their peers, managers appraised both their own and their peers' emotions; and for their subordinates the integrating style was not a popular option.

\subsection{Emotional intelligence and the avoiding style}

$\mathrm{ROE}$ and use of emotions adaptively (UOE) would likely drive managers towards the avoidance style in conflicts that involved their peers and supervisors. Empathy and control are lacking in conflicts involving their subordinates. Appraisal of one's own and others' emotions are not employed by the Chinese managers when the avoidance style is adopted.

\subsection{Emotional intelligence and the dominating style}

Use of emotions adaptively (UOE), understanding others' emotions (OEA) and SEA would affect managers to adopt the dominating style when dealing with their peers in conflicts. In instances of conflict with their supervisors, understanding others' emotions (OEA) and SEA were the two significant components. This finding partially supports Rahim (1983).

\subsection{Emotional intelligence and the obliging style}

When peers and supervisors were involved in conflict with the Chinese managers, they tended to regulate their own emotions (ROE) and use of them adaptively (UOE) as the obliging style seems to require higher levels of concern for others as indicated in Rahim (1983). When their subordinates were involved, they would choose the obliging style only when they placed the emotions of others at the centre of the situation.

\subsection{Emotional intelligence and the compromising style}

In the adoption of the compromising style involving their colleagues at any level, the Chinese managers did not seem to need to regulate their emotions (ROE). They were extremely emotionally intelligent when their peers and supervisors were involved as they would appraise not only their own but also others' emotions. When their subordinates were 
IJOA

27,3

\section{8}

involved, their use of emotions adaptively (UOE) was the only significant component to motivate them to adopt the compromising style.

In conclusion, the most significant component of EI is the use of emotions adaptively (UOE) among the Chinese managers in conflict management, particularly when their peers and supervisors were involved in conflicts. In comparison, the Chinese managers were least likely to appraise their own emotions (SEA) in conflict management.

\section{Implications for management}

The overall achievement of this study is satisfactory, contributing to a better understanding of how the Chinese managers use their EI in different scenarios of conflicts involving their subordinates, peers and superiors. The research outcome suggest that managers working in the public sector were found to be more predictable than those working in the private sectors in adopting the integrating, avoiding, obliging and compromising approaches in conflicts with their peers, and the avoiding styles when they were involved in conflicts with their supervisors respectively. In our previous studies, findings suggested managers in the public sectors tend to possess higher levels of EI than managers in private sectors. Therefore, they are more skilful in using their EI more adaptively, which is an advantage when it comes to the adoption of different conflict management styles, as confirmed in this study. Education was significant only in situations when managers were involved in conflicts with their peers. Those managers with less education tended to choose the avoiding style in interactions with their peers, and at the same time, they tended to regulate their emotions and use them adaptively. The adoption of conflict management styles does not seem to be related to age. Only younger Chinese managers are more likely to choose the compromising style when they find themselves in conflict with their superiors. Managers at a senior level tended to choose the avoiding style when dealing with their colleagues, and the junior managers were likely to opt for the dominating style in conflicts involving their subordinates. The above findings might be surprising to some practitioners in relation to Chinese culture, which arguably exhibits a higher power distance. Our findings indicate that older or senior managers do not adopt the dominating style in conflicts involving their younger or junior counterparts.

\section{Limitations and recommendations for future work}

An investigation such as our study faces some limitations with regard to methodology. First, we only targeted managers living and working in Dalian, and who are current MBA and MPA students, or on the alumni, of a national university. The results may well be lacking in generalizability, and it would therefore be interesting to see further studies that extend the sample size to broaden the analysis. The second limitation of this study relates to the fact that we asked each respondent only to indicate how they deal with conflict in only one specific scenario involving either their peers, subordinates or superiors. This approach was adopted to increase the accuracy of the data. Future studies should be carried out to investigate how variation exists in one individual when it comes to managing numerous conflicts involving their peers, subordinates or superiors.

\section{References}

Abas, N.A.H. Surdick, R. Otto, K. Wood, S. and Budd, D. (2014), "Emotional intelligence and conflict management styles", available at: www.researchgate.net

Ann, B.Y. and Yang, C.C. (2012), "The moderating role of personality traits on emotional intelligence and conflict management styles", Psychological Reports, Vol. 110 No. 3, pp. 1021-1025. 
Aquino, K., Tripp, T.M. and Bies, R.J. (2006), “Getting even or moving on? Power, procedural justice, and types of offense as predictors of revenge, forgiveness, reconciliation, and avoidance in organizations", Journal of Applied Psychology, Vol. 91 No. 3, pp. 653-668.

Aritzeta, A., Ayestaran, S. and Swailes, S. (2005), "Team role preference and conflict management styles", International Journal of Conflict Management, Vol. 16 No. 2, pp. 157-182.

Ayoko, O.B., Callan, V.J. and Härtel, C.E.J. (2003), "Workplace conflict, bullying, and counterproductive behaviors", The International Journal of Organizational Analysis, Vol. 11 No. 4, pp. 283-301.

Bar-On, R. (1997), The Emotional Intelligence Inventory (EQ-i): Technical Manual, Multi-Health Systems, Toronto.

Blake, R.R. and Mouton, J.S. (1964), The Managerial Grid, Guld Publishing, Houston, TX.

Cartwright, S. and Pappas, C. (2008), "Emotional intelligence, its measurement and implications for the workplace", International Journal of Management Reviews, Vol. 10 No. 2, pp. 149-171.

Caruso, D.R., Mayer, J.D. and Salovey, P. (2002), "Emotional intelligence and emotional leadership", in Riggio, R.E. and Murphy, S. (Eds), Multiple Intelligences and Leadership, Lawrence Erlbaum, Mahwah, NJ, pp. 55-74.

Conine, T.E. and Leskin, B. (2016), "Developing emotional intelligence and conflict management skills through the 360 assessment", Global Business and Organizational Excellence, Vol. 35 No. 3, pp. 18-26, March/April.

Darling, J.R. and Walker, W.E. (2001), "Effective conflict management: use of behaviour style model", Leadership and Organization Development Journal, Vol. 22 No. 5, pp. 230-242.

Deutsch, M. (1949), "A theory of cooperation and competition”, Human Relations, Vol. 2 No. 2, pp. 129-151.

Goleman, D. (1995), Emotional Intelligence, Bantam Books, New York, NY.

Goleman, D. (1998), Working with Emotional Intelligence, Bantam Books, New York, NY.

Hellriegel, D., Slocum, J.W., Jr and Woodman, R.W. (1995), Organisational Behaviour, 7th Ed. West Publishing, New York, NY.

Horney, K. (1945), Our Inner Conflict: A Constructive Theory of Neurosis, Norton and Company, New York, NY.

Jehn, K.A. (1995), "A multimethod examination of the benefits and detriments of intra-group conflict", Administrative Science Quarterly, Vol. 40 No. 2, pp. 256-282.

Jehn, K.A. (1997), “A qualitative analysis of conflict types and dimensions in organisational groups", Administrative Science Quarterly, Vol. 42 No. 3, pp. 530-557.

Ji, J. (2012), "Chinese people's self-construal and its relationship with conflict management styles", Public Personnel Management, Vol. 4 No. 2, pp. 69-78.

Jordan, P.J. and Troth, A.C. (2004), "Managing emotions during team problem solving: emotional intelligence and conflict resolution", Human Performance, Vol. 17 No. 2, pp. 195-218.

Johnson, D.W. and Johnson, F.P. (2000), Joining Together: Group Theory and Group Skills, 7th eds, Allyn and Bacon, Boston.

Kerr, R., Garvin, J., Heaton, N. and Boyle, E. (2006), "Emotional intelligence and leadership effectiveness", Leadership and Organization Development Journal, Vol. 27 No. 4, pp. 265-279.

Mayer, J.D. and Salovey, P. (1997), "What is emotional intelligence?”, in Salovey, P. and Sluyter, D.J. (Eds), Emotional Development and Emotional Intelligence: Educational Implications, Basic Books, New York, NY, pp. 3-31.

Mayer, J.D., Caruso, D.R. and Salovey, P. (1999), "Emotional intelligence meets traditional standards for an intelligence", Intelligence, Vol. 27 No. 4, pp. 267-298.

Mayer, J.D., Salovey, P. and Caruso, D.R. (2000), "Models of emotional intelligence”, in Sternberg, R.J. (Eds), The Handbook of Intelligence, Cambridge University Press, New York, NY, pp. 396-420. 
IJOA 27,3

Moberg, P.J. (2001), "Linking conflict strategy to the five-factor model: theoretical and empirical foundations", International Journal of Conflict Management, Vol. 12 No. 1, pp. 47-68.

Moeller, C. and Kwantes, C.T. (2015), "Too much of a good thing? Emotional intelligence and interpersonal conflict behaviors", The Journal of Social Psychology, Vol. 155 No. 4, pp. 314-324.

Nair, N. (2007), "Toward understanding the role of emotions in conflict: a review of future directions", International Journal of Conflict Management, Vol. 19 No. 4, pp. 359-381.

Pruitt, D.G. (1983), "Strategic choice in negotiation”, American Behavioral Scientist, Vol. 27 No. 2, pp. 167-194.

Rahim, M.A. (1983), "A measure of styles of handling interpersonal conflict”, Academy of Management Journal, Vol. 26, pp. 368-376.

Rahim, M.A. and Bonoma, T.V. (1979), "Managing organisational conflict: a model for diagnosis and intervention", Psychological Reports, Vol. 44 No. 3, pp. 1323-1344.

Rahim, M.A. and Magner, N.R. (1995), "Confirmatory factor analysis of the styles of handling interpersonal conflict: first-order factor model and its invariance across groups", Journal of Applied Psychology, Vol. 80 No. 1, pp. 122-132.

Rahim, M.A. and Psenicka, C. (2002), "A model of emotional intelligence and conflict management strategies: a study in seven countries", The International Journal of Organizational Analysis, Vol. 10, pp. 302-326.

Rahim, M.A., Garret, J.E. and Bunzman, G.R. (1992), "Ethics of managing interpersonal conflicts in organizations", Journal of Business Ethics, Vol. 11 No. 5, pp. 423-432.

Salovey, P. and Mayer, J.D. (1990), "Emotional intelligence", Imagination, Cognition and Personality, Vol. 9 No. 3, pp. 185-211.

Schutte, N.S., Malouff, J.M., Hall, L.E., Haggerty, D.J., Cooper, J.T., Golden, C.J. and Doornheim, L. (1998), "Development and validation of a measure of emotional intelligence", Personality and Individual Differences, Vol. 25 No. 2, pp. 167-177.

Suliman, A.M. and Al-Shaikh, F.N. (2006), "Emotional intelligence at work: links to conflict and innovation”, Employee Relations, Vol. 29 No. 2, pp. 208-220.

Thomas, K.T. (1992), "Conflict and conflict management: reflections and update", Journal of Organizational Behavior, Vol. 13 No. 3, pp. 265-274.

Ting-Toomey, S. (1999), Communication across Cultures, The Guilford Press, New York, NY and London.

Weiss, J. and Hughes, J. (2005), “Want collaboration? Accept - and actively manage - conflict”, Harvard Business Review, Vol. 83 No. 3, pp. 1-10.

Wong, C.S. and Law, K.S. (2002), "The effects of leader and follower emotional intelligence on performance and attitude: an exploratory study", The Leadership Quarterly, Vol. 13 No. 3, pp. 243-274.

\section{Further reading}

Atteya, N.M. (2012), "The conflict management grid: a selection and development tool to resolve the conflict between the marketing and sales organisations", International Journal of Business and Management, Vol. 7, pp. 28-39.

Shih, H.-A. and Susanto, E. (2010), "Conflict management styles, emotional intelligence, and job performance in public organizations", International Journal of Conflict Management, Vol. 21 No. 2, pp. 147-168.

\section{Corresponding author}

Helen X. Chen can be contacted at: hchen@dit.ie

For instructions on how to order reprints of this article, please visit our website:

www.emeraldgrouppublishing.com/licensing/reprints.htm

Or contact us for further details: permissions@emeraldinsight.com 